\title{
A aposentadoria compulsória e os proventos dos professôres catedráticos
}

Julgando-se prejudicado com os atos do Govêrno do Estado de São Paulo, por via dos quais foi aposentado compulsòriamente no cargo de professor catedrático de História do Direito Nacional, o dr. Waldemar Ferreira intentou ação contra a Fazenda do Estado a fim de ver restaurado seu direito ao tempo em que se achou afastado de sua cátedra em virtude da desacumulação forçada estabelecida pelo regime instaurado em 1937.

Logrou êxito a ação, de conformidade com a seguinte sentença:

"Vistos, etc.

"O Doutor Waldemar Martins Ferreira, professor emérito e lente aposentado da Faculdade de Direito da Universidade de São Paulo, propôs a presente ação ordinária contra a Fazenda do Estado, pedindo :

a) a condenação da ré ao pagamento da diferença de proventos de sua aposentadoria, correspondente ao tempo em que esteve afastado de sua cátedra de História do Direito Nacional, por desacumulação forçada;

b) a condenação da mesma ré ao pagamento da r'emuneração referente às licenças-prêmios que não gozou e outras mais vantagens a que tenha direito ou que lhe possam advir, em virtude de seu cargo;

c) o cancelamento do despacho do Magnífico Reitor da Universidade de São Paulo, datado de 8 de fevereiro de 1956, com a conseqüente cessação das deduções de venci- 
mentos do autor e restituição das que lhe hajam sido feitas;

d) a condenação da ré nos juros da mora, nas custas e em honorários de advogados.

"Pediu também a citação da Universidade de São Paulo para os têrmos da demanda.

I. Alega, em resumo, que, sendo professor catedrático de Direito Comercial no curso de Bacharelado da Faculdade de Direito desde o ano de 1925, regeu o autor na mesma escola e no seu curso de Doutorado, também como catedrático, a cadeira de História de Direito Nacional, desde que para esta foi nomeado por Decreto de 8 de junho de 1934. Suprimida esta última cadeira em 31 de dezembro de 1935, passou o autor à disponibilidade remunerada.

"Muito embora tenha o autor deixado de perceber os vencimentos correspondentes a tal disponibilidade, por motivos de ordem moral revelados em ofício dirigido ao Secretário da Educação e Saúde do Estado, ressalvou todos os demais direitos peculiares ao seu cargo de professor catedrático.

"Sobrevindo a carta de 1937, esta vedou, em seu art. 159 , as acumulações remuneradas. E havendo o art. $2 .^{\circ}$ do Decreto-Iei n. 24 , de 1937, determinado que os funcionários optassem, dentro em trinta dias, entre os cargos e funções, preferiu o autor a sua cátedra de Direito Comercial, no curso do Bacharelado. Em virtude dessa opção compulsória, foi êle exonerado, a partir de 1 de janeiro de 1938, do cargo de professor catedrático de História do Direito Nacional.

"Contudo, por fôrça do art. 24 do Ato das Disposições Constitucionais Transitórias, promulgado aos 18 de outubro de 1946, foi o autor, por Decreto de 20 de outubro de 1946, declarado em disponibilidade remunerada na cadeira de História do Direito Nacional.

"Reaproveitado, por ato de 13 de março de 1947, passou êle a lecionar a referida disciplina, o que fêz até 
sua aposentação forçada, por efeito de idade, em 2 de dezembro de 1950.

"Ao se fixarem administrativamente os proventos de sua aposentadoria, não lhe foi contado o tempo que estêve afastado, por desacumulação forçada, da sua cadeira de História do Direito do Direito Nacional, desde janeiro de 1938 até setembro de 1946.

"Contra essa lacuna reclamou o autor junto ao Reitor da Universidade de São Paulo e, em grau de recurso, ao Governador do Estado. Não atendido na instância administrativa, volta-se o autor para o Poder Judiciário.

"Fundaram-se as autoridades administrativas na conhecida distinção entre reintegração e readmissão, sem atentar na possibilidade de figuras intermédias e desconhecendo o escopo do art. 24 do Ato das Disposições Constitucionais Transitórias.

"No que toca as deduções de vencimentos:

"Dispondo sôbre a situação criada para os professôres da Faculdade de Direito de São Paulo, funcionários da União, com a passagem dela para o regime administrativo estadual, o Decreto federal $\mathrm{n}^{\circ}{ }^{0} 24.202$, de 1934, art. $2 .^{\circ}$, alínea $b$ ), estipulou:

"Aos atuais professôres e funcionários da Faculdade de Direito são garantidos os direitos e as vantagens que as leis federais lhes asseguram, inclusive o pagamento dos respectivos vencimentos pelo Tesouro Nacional, sem embargo de outros direitos que leis estaduais outorguem a professôres e funcionários de igual categoria".

"Por sua vez, o Decreto-lei estadual n. ${ }^{\circ}$ 17.148, de 1947, art. $1 .^{\circ}$, dispôs:

"Aos professôres catedráticos da Faculdade de Direito transferida pelo Govêrno da União ao de São Paulo, fica assegurada a diferença de vencimentos entre os que percebem ou venham a perceber os professôres catedráticos estaduais da Universidade e os que, por lei federal, couberem ou venham a caber em geral aos referidos professôres". 
"Ora, aos funcionários da União foi concedido abono provisório, em virtude da lei federal n. ${ }^{\circ}$ 2.412, de 1952. Dito abono, dispôs a mesma lei, no art. $6 .^{\circ}$, não seria, em caso algum, nem para qualquer efeito, incorporado ao vencimento, remuneração, salário ou retribuição do servidor, nem ao provento da inatividade ou pensão.

"Sem embargo, entenderam as autoridades universitárias paulistas não ser lícito ao autor perceber o abono federal e, ao mesmo tempo, a totalidade de seus vencimentos estaduais, porque viria êle a receber, no seu todo, proventos superiores aos percebidos, mensalmente, pelos professôres estaduais exclusivamente do regime estadual.

"Contra essa resolução insurgiu o autor inùtilmente, na esfera administrativa.

"É certo, no entanto, que no regime político constitucional vigente as leis da União e os seus efeitos não podem ser despresados ou invalidados, direta ou obliquamente, por leis ou atos estaduais.

"Com a inicial vieram os documentos.

"A Universidade de São Paulo declarou que subscrevia, antecipadamente, a contestação que a Fazenda do Estado houvesse por bem oferecer.

"A Fazenda do Estado contestou, afirmando, em síntese, que o art. 24 do Ato das Disposições Constitucionais Transitórias permitiu o retôrno aos cargos exercidos cumulativamente ao tempo da carta de 1937. Mas o fêz em caráter de readmissão. É solução já firmada por decisões do Tribunal de Justiça do Estado e do Supremo Tribunal Federal.

"Tratando-se de readmissão, seus efeitos estão delimitados pelo que dispõe o art. 77 do Estatuto dos Funcionários Públicos. Ademais, constituindo norma de caráter excepcional, o art. 24 do Ato das Disposições Constitucionais Transitórias há de ser entendido de modo restrito.

"Quanto ao segundo ponto, era também de ser repelido, nos têrmos do parecer da Consultoria Jurídica da Universidade, integralmente transcrito na contestação. 
"O processo foi saneado.

"Em audiência, as partes produziram as alegações que constam do têrmo e do memorial, reiterando os argumentos já resumidos.

"É o relatório.

"Passo a decidir.

II. É indubitável que a reintegração e a readmissão não se confundem. A reintegração, que decorre de decisão administrativa ou judiciária, transitada em julgado, determina o ressarcimento das vantagens ligadas ao cargo. Pela readmissão, o funcionário reingressa, pura e simplesmente, ao serviço público, sem direito a ressarcimento de prejuízos (cfr. Decreto-lei estadual n. ${ }^{\circ} 12.273$, de 1941 , art. 76 e 77 ; lei federal n. ${ }^{\circ} 1.711$, de 1952, arts. 58 a 62).

"A reintegração pressupõe a ilegitimidade do afastamento ou da extinção do cargo ou função. Ao contrário, do que ocorre com a readmissão, a reintegração não implica em nova nomeação, e menos ainda em solução de continuidade na relação de emprêgo público. A reintegração não é mera faculdade, mas sim um dever da administração pública ${ }^{1}$.

"É bem de ver, porém, que o legislador, e mais que todos o constituinte, não está impedido de criar figuras intermédias. Ao fím e ao cabo, não vivemos naquele céu dos conceitos jurídicos tão espirituosamente descritos por InerING (Serio e Faceto nella Giurisprudenza, trad. Lovaggi, pág. 318 e segs.), no qual a pureza das figuras jurídicas constituia o mais grave dos delitos. Mais de uma vez, em luminosos votos, a Ministro Orosimbo Nonato, a propósito dos arts. 24 e 30 do Ato das Disposições Consti: tucionais Transitórias (Cfr. Revista de Direito Administrutıvo, 41/170) tem ensinado que entre a simples readmissão e a verdadeira reintegração pode figurar uma situação

(1) Cfr. Basavilbaso, Derecho Administrativo, vol. III, ns. 419 a 421 . 
intermédia: reintegração com um minus, reintegração sem um dos seus efeitos (no caso, sem direito aos vencimentos).

"Ora, o eminente José Duarte tornou claro que o legislador constituinte pretendeu, com o art. 24 do Ato das Disposições Constitucionais, conferir ampla reparação, excluída apenas a percepção dos vencimentos anteriores, aos funcionários atingidos pelo Decreto-lei n. ${ }^{\circ}$ 24, de 1937. Este diploma, pondo fim às acumulações remuneradas, não respeitou o direito de vitaliciedade de cargos obtidos por concurso e cujo exercício cumulativo se fundava em permissão constitucional expressa. Feriu direitos adquiridos que podiam e deviam ter sido resguardados, mesmo na vigência da carta de 1937.

"Por isso, entendeu o constituinte de 1946 de restaurar os direitos dos funcionários que foram demitidos dos seus cargos vitalícios por fôrça de opções determinados pelo Decreto-lei n. ${ }^{\circ} 24$, de $1937^{2}$.

“Em resumo: o legislador constituinte considerou ilegítimos os afastamentos obrigados pelo Decreto-lei n." 24 de 1937, e deliberou restabelecer para os funcionários atingidos o direito vitalício de que haviam sido despojados.

"Evidente é, assim, o caráter de ressarcimento do retôrno prescrito pelo art. 24 do Ato das Disposições Constitucionais Transitórias. Reparação incompleta, não há dúvida, porque dela excluída a percepção dos vencimentos anteriores a 18 de setembro de 1946. Mas sempre reparação. Trata-se, portanto, de verdadeira reintegração, embora sem um dos seus efeitos.

"O preceito reconhece o direito ao cargo, e direito que remonta à data em que fôra do mesmo afastado.

"Logo, se direito impostergável, cabem ao seu titular tôdas as vantagens que lhe são próprias, inerentes, vinculadas, pois que, do contrário, não seria uma reintegração completa, uma completa reparação, o reconhecimento de

(2) A Constituição Brasileira de 1946, vol. III, págs. 496/499. 
um direito, mas uma liberalidade, uma concessão, um benefício.

“Uma dessas vantagens - e por ser tão absoluto o princípio - se exclui apenas porque o prescrito constitucional, êle próprio, o eliminou expressamente: a percepção dos vencimentos anteriores (JosÉ DuARTE, ob. e vol. cits, pág. 498).

"Nem se censure o recurso ao elemento histórico. 0 que a doutrina recrimina é o abuso dos trabalhos preparatórios na interpretação das leis. Guardadas as necessárias cautelas, o elemento histórico é mui legìtimamente empregado para, como diz GeNy arrancar ao texto legal o seu enigma, ou, melhor, lhe penetrar o sentido ${ }^{3}$

"Nem se deve esquecer que as Constituições, longe de merecerem um tratamento estritamente técnico, devem ser interpretadas liberalmente, e suas expressões esclarecidas "by studing the facts of contemporary history and the purpose sought, to be accomplished, and the benefit to be secured, or the evil to be remedied, by the provision in question" ${ }^{4}$.

"No que toca à jurisprudência do Supremo Tribunal Federal, é preciso considerar que a decisão invocada pela ré versa caso em que o funcionário pleiteava efeitos bem diversos dos que pede o autor, nesta ação.

"Trata-se, ademais, de decisão tomada por simples maioria de votos, parte dos quais se deteve no exame de matéria preliminar, e que, em embargos, foi confirmada exclusivamente por fôrça do art. 838 parág. $10^{\circ}$, do Código de Processo Civil, pôsto que ocorreu empate na votação ${ }^{5}$. Há mais porém.

(3) Méthodes d'Interpretation et Sources en Droit Privé, seg. ed., vol. I, págs. 286 e segs., ns. 287 a 285.

(4) BLACK, Handbook of American Constitution Law, 3. ${ }^{\text {a }}$ ed., págs. $75 / 77$, ns. 47/49).

(5) Rev. Dir. Adm. 18/106. 
"Posteriormente o Supremo Tribunal Federal firmou de maneira definitiva o entendimento de que o art. 24 do Ato das Disposições Constitucionais Transitórias, não tendo feito mais que restaurar os direitos preexistentes dos funcionários demitidos por efeito da desacumulação ordenada em 1937, implicava em verdadeira reintegração dêsses servidores.

"Tal jurisprudência se formou a propósito do cálculo dos proventos da disponibilidade assegurada pelo mesmo art. 24 do Ato das Disposições Constitucionais Transitórias. Havia a Presidência da República, adotando parecer do D.A.S.P., ${ }^{6}$ mandado que os proventos da disponibilidade fôssem calculados na proporção do têrmo de serviço como aliás, determinava o art. 194 do dec. lei n. 1.713, de 1939 - computado o que mediara entre a exoneração ou demissão e o dia 18 de setembro de 1946. O que já implicava, não obstante os protestos em contrário da administração, na admissão do caráter reparatório do art. 24 do Ato das Disposições Constitucionais Transitórias. Mas o Supremo Tribunal Federal foi além, decidindo que a disponibilidade assegurada no mencionado artigo era com vencimentos integrais, pôsto que ali se cuidava de restaurar direitos preexistentes ${ }^{7}$

"Não se pode negar ao autor, portanto, o direito de ver contado, para efeito de cálculo dos proventos de sua aposentadoria, e demais vantagens inerentes ao seu cargo de catedrático de História do Direito Nacional, o tempo em que dêle estêve afastado, por desacumulação forçada.

"III. Passamos às deduções de vencimentos que o autor vem sofrendo, por parte do Estado, em razão do abono provisório que the vem pagando a União. $O$ dec. lei estadual n. ${ }^{\circ} 17.118$, de 1947, art. 7, dispôs: "Aos protessôres catedráticos da Faculdade de Direito transferida pelo Govêrno da União ao de São Paulo, fica assegurada

(6) Rev. Dir. Adm. 12/383, 14/419.

(7) Rev. Dir. Adm., 44/258, 42/168, 35/141. 
a diferença de vencimentos entre os que percebem ou venham a perceber os professôres catedráticos estaduais da Universidade e os que, por lei federal couberem ou venham a caber em geral aos referidos professôres". Tirase do texto legal simplesmente que aos professôres catedráticos, estipendiados pela União por fôrça do artigo $2 .^{\circ}$ alínea " $b$ ", do dec. federal 24.102 de 1934, era garantido o direito de receber do Estado a diferenca entre os seus vencimentos, e os dos professôres catedráticos estaduais.

"A Universidade porém foi mais longe, e, não sem algum esfôrço, extraiu daquele diploma legal o princípio da equiparação reciproca entre os vencimentos dos professôres estaduais e federais, da Faculdade de Direito. Contudo, ainda que se admita a interpretação construtiva levada a têrmo pelos dignos consultores da Universidade, parece-me indubitável que a mesma não pode conduzir à redução de vencimentos de que se queixa o autor.

"O abono especial temporário, consoante os têrmos incisivos da lei Federal 2.412, de 1955, art. 6. ${ }^{\circ}$, "não será, em caso algum nem para qualquer efeito, incorporado ao vencimento, remuneração, salário ou retribuição do servidor, nem ao provento do inativo ou pensionista, não sendo ainda computada na concessão de qualquer vantagem, salvo para o cálculo de serviço extraordinário". Não há interpretação finalística que logre cancelar mandamento assim terminante. Note-se que o dec. lei estadual $n .^{\circ}$ 17.118 de 1947, se referiu a diferença de vencimentos. Não se valeu de expressões mais amplas, como "vantagens pecuniárias" ou "estipêndio", que permitissem a inclusão do abono especial temporário, para o cálculo da diferença.

"No direito administrativo, assim da União, (Lei federal n. ${ }^{\circ}$ 1.711, de 1952, art. 119) como do Estado (dec.lei estadual n. ${ }^{\circ} 12.273$, de 1941, art. 106), vencìmento é a retribuição pelo efetivo exercício do cargo, correspondente ao padrão fixado em lei. Parece evidente, assim, que a diferença de vencimentos há de ser computada com base nos padrões fixados em lei. $O$ mesmo se há de dizer 
quanto aos proventos do inativo, fixados sempre em função dos vencimentos.

"Nem cabe ao Estado membro derrogar normas de direito administrativo federal.

"É a União que há de dizer, quanto aos seus funcionários, o que é, e o que não é vencimento ou provento. Referindo-se aos vencimentos que, por lei federal, caibam aos professôres pagos pela União, a lei estadual fêz seus conceitos de direito administrativo federal, que aliás, como se disse acima, não discrepam dos que vigoram no âmbito estadual. É assim, de todo modo indefensável, a dedução que vem sofrendo o autor.

"IV. Isto pôsto, julgo procedente a ação, em parte, para o fim de:

“a) declarar que cabe ao autor o direito de ver contado, para efeito de cálculo dos proventos de sua aposentadoria, e demais vantagens decorrentes de seu cargo de catedrático de História do Direito Nacional, com a única exceção dos vencimentos anteriores à data da promulgação do Ato das Disposições Constitucionais Transitórias, o tempo em que dêle estêve afastado por desacumulação forçada;

“b) condenar a ré a pagar a diferença dos proventos, resultante da inclusão do período de desacumulação forçada, e demais vantagens, conforme se apurar em execução;

c) declarar que da diferença de vencimentos paga ao autor, nos têrmos do dec.-lei estadual n. ${ }^{\circ} 17.118$, de 1947, não deve ser deduzida a importância recebida como abono especial temporário, em razão da lei federal n. ${ }^{\circ} 2.412$, de 1955;

“d) condenar a ré a restituir as deduções já operadas, e a se abster delas de futuro;

“e) condenar a ré a pagar os juros da mora, calculados na forma do dec. 22.785 de 1933.

"Honorários de advogado não são devidos, por não se ter configurado nenhuma das hipóteses do art. 64 do Có- 
digo de Processo Civil. Apenas nessa parte fica vencido o autor.

"Custas em proporção.

"Recorro de ofício.

"Publique-se na audiência designada.

"São Paulo, 25 de outubro de 1957. - Dinio DE SANTis GARCIA, Juiz de Direito".

Confirmou-se essa sentença pelo seguinte:

\section{Acórdão.}

"Vistos, relatados e discutidos êstes autos de apelação cível n. ${ }^{\circ} 86.260$, da comarca de São Paulo, em que são apelantes o Juízo ex-officio e a Fazenda do Estado, sendo apelado o Dr. Waldemar Martins Ferreira:

"Acordam em Quinta Câmara Civil do Tribunal de Justiça, por votação unânime, depois de adotado como parte integrante dêste o relatório de fls., negar provimento aos recursos para que subsista, por seus próprios e juridicos fundamentos, a bem elaborada sentença recorrida.

"Custas, como de direito.

"São Paulo, 21 de março de 1958. - Luiz Morato, Presidente, com voto. - J. G. Rodrigues Alckmin, Relator. Alcides Faro, Revisor". 